\title{
AN EVALUATION OF THE EFFECTIVENESS OF THE AUTHENTIC TASK ON STUDENTS' LEARNING ACHIEVEMENT OF PLANT ANATOMY CONCEPTS IN SURABAYA STATE UNIVERSITY
}

\author{
Enny Susiyawati, S.Si ${ }^{1)}$ \\ Prof. Dr. Muslimin Ibrahim, M.Pd. \\ Prof. Bill Atweh ${ }^{3)}$ \\ Dr. sc. agr. Yuni Sri Rahayu, M.Si ${ }^{2)}$ \\ ${ }^{1)}$ Student of Science Education Department of Postgraduate Program, Surabaya State University \\ ${ }^{2}$ Lecturer of Science Education Department of Postgraduate Program, Surabaya State University \\ ${ }^{3)}$ Lecturer of Science and Mathematics Education Department of Postgraduate Program, Curtin University, WA \\ e-mail : susiyawatienny@gmail.com
}

\begin{abstract}
To promote the knowledge of plant anatomy which is frequently taught using traditional method, students need to be involved in authentic learning by providing them an authentic task. Therefore, the aims of this current research are to implement a certain authentic task of plant anatomy; to evaluate the effectiveness of the task on the students' learning achievement includes their performances, knowledge mastery, and perceptions of the task; and to describe some difficulties that occurred during the implementation of the authentic task. This case study research involved a single class consisted of 25 bachelor degree students as the subjects of this research. Observation, interview, and test were implemented to collect variety information during implementation of the authentic task. The findings showed that the students' performance scores and the percentage of mastered indicators met the minimum mastery criteria, but the percentage of classical mastery was less than the criteria. It means the authentic task had positive impact only on students' performance, but it could not help the whole students to master the topic. However, regarding to perception, both higher and lower achiever students thought the task was authentic. Nevertheless, there were four obstacles occurred during implementation of the authentic task, they were students' confusion of the task, students' difficulty to make microscope slides, students' difficulty to identify plant structures, and the limited time. Overall, it can be concluded that, contrary to what was expected, the implemented authentic task in this study was not effective for the learners in order to get a good holistic learning achievement due to the difficulties. Therefore, in designing a well authentic task, the educators or developer need to think not only the task, but also students' skills and time allocation.
\end{abstract}

Keywords: Plant anatomy, authentic task, students' learning achievement.

\begin{abstract}
Abstrak: Dalam rangka meningkatkan pengetahuan tentang anatomi tumbuhan yang biasanya diajarkan melalui metode tradisional, siswa perlu dilibatkan dalam pembelajaran autentik melalui pemberian tugas autentik. Oleh karenanya, tujuan penelitian ini ialah untuk menerapkan suatu tugas autentik tentang anatomi tumbuhan; untuk mengevaluasi keefektivan tugas tersebut terhadap hasil belajar siswa yang meliputi hasil kinerja, ketuntasan materi ajar, dan persepsi siswa terhadap tugas tersebut; serta untuk mendeskripsikan kesulitan-kesulitan yang terjadi selama penerapan tugas autentik. Penelitian dengan tipe penyelidikan kasus ini melibatkan satu kelas yang terdiri atas 25 siswa S1 sebagai subjek penelitian. Pengamatan, wawancara, dan tes diterapkan untuk mengumpulkan berbagai informasi selama penerapan tugas autentik. Hasil penelitian menunjukkan bahwa skor kinerja siswa dan persentase ketuntasan indikator memenuhi kriteria ketuntasan minimum, tetapi persentase ketuntasan klasikal tidak mencapai kriteria tersebut. Hal tersebut berarti tugas autentik yang diterapkan memiliki dampak positif hanya terhadap hasil kinerja siswa, tetapi tugas tersebut belum dapat membantu seluruh siswa untuk menuntaskan materi ajar. Walaupun demikian, berkaitan dengan persepsi siswa, baik siswa yang memperoleh nilai tinggi maupun rendah menganggap tugas tersebut autentik. Akan tetapi, terdapat empat kendala yang terjadi selama penerapan tugas autentik tersebut, yaitu: kebingungan siswa terhadap tugas yang diberikan; kesulitan siswa dalam membuat preparat dan mengidentifikasi struktur tanaman; serta keterbatasan waktu yang tersedia. Jadi, dapat disimpulkan bahwa, berbeda dengan yang diharapkan, tugas autentik yang diterapkan dalam penelitian ini tidak effektif bagi siswa dalam rangka memperoleh hasil belajar holistik yang baik karena kesulitan-kesulitan yang muncul selama penerapannnya. Oleh karena itu, dalam merancang suatu tugas autentik yang baik, pengajar perlu memikirkan tidak hanya tugas autentik itu sendiri, tetapi juga keterampilan siswa dan alokasi waktu.
\end{abstract}

Kata Kunci: Anatomi tumbuhan, tugas autentik, hasil belajar siswa.

\section{INTRODUCTION}

Mostly, teaching of plant anatomy at university still relies on teacher centered management ${ }^{[9][26]}$. The emphasis of these conventional approaches has been on rote learning and teaching them in abstract and decontextualised forms. As a result, students are less able to integrate and to apply the concepts that they have learned to solve problems in their daily life since the knowledge was stored only as an information rather than as a tool for solving problems ${ }^{[18]}$.

For that reason, it is thought that students need to be involved in the learning activity which allows them to get real experiences and the relevancy of real world to their work. One of the alternative approaches to achieve these purposes is by involving students in authentic learning. According to Herrington et al. ${ }^{[18]}$, the authentic learning refers to a learning method which encourages students to 
involve in real-world relevant tasks. Thus, students can be involved in authentic learning experiences by providing them appropriate authentic tasks. A welldesigned authentic task does not only provide an opportunity to practice learning and to develop certain skills ${ }^{[18]}$, but also affects their involvement and motivation toward learning process ${ }^{[22]}$. As Neo and Neo [23] in their study of multimedia project found that authentic task can encourage students to be active and highly motivated learners. Similarly, Gulikers et al. ${ }^{[14]}$ observed that increasing the task authenticity can encourage students to learn deeply. In other words, the authentic tasks can affect students' learning achievement by increasing their motivation to learn.

However, Gulikers et al. ${ }^{[15]}$ warned that authenticity is a subjective matter which means that different students may have different perceptions of the same authentic tasks. Furthermore, Biggs (as cited in ${ }^{[14]}$ ) asserted that students' perception of learning enable to affect their learning outcomes. Thus, in order to provide a meaningful authentic task for improving students' learning, educators in designing the task need to think about students' perception.

In addition to perception, the authentic tasks will be more useful, fair, and equitable for students if they are assisted by a precise type of assessment ${ }^{[24]}$, that is, authentic assessment. Wiggins (as cited in ${ }^{[10]}$ ) defined the authentic assessment as one alternative of students' performance evaluation on the tasks which are relevant to their real life. According to Darling-Hammond et al. ${ }^{[10]}$, this assessment enabled to assess the actual students' abilities, such as performance, higher order thinking, and problem solving, which cannot be assessed by traditional paper-and-pencil test which focuses only on memorizing knowledge. However, since Indonesian government still uses standardized test in civil workers recruitment to measure the employability. Hence, in this case, the two types of assessment, the authentic assessment and the paper-and-pencil test, will be more useful if they are implemented together.

As such reasons, this study was established by implementing a certain authentic task that simulated botanist' jobs as an alternative teaching method for plant anatomy subject. The objectives of this study were: a) to implement a certain authentic task of plant anatomy; b) to evaluate the effectiveness of the task on the students' learning achievement includes their performances, knowledge mastery, and perception of the task; and c) to describe some difficulties that occurred during the implementation of the authentic task.

\section{RESEARCH METHOD}

Participants
This case study research involved a single class that consisted of 25 bachelor degree students of Surabaya State University studying plant anatomy as subject of research. The class was selected because it was a small class and the students were considered by many lecturers had better learning ability rather than the others. Therefore, arguably, the class was suitable for implementation of new teaching method.

\section{Procedure}

The current research was conducted within two phases. The first phase was designing of teaching materials and research instruments. The teaching materials included lesson plan and authentic task were designed in order to guide implementation of the authentic task in the class, whereas the research instruments functioned to collect data. The second phase was development of them. This phase consisted of two stages, they were validation and implementation. The former functioned to get some suggestions from the experts in designing as perfect teaching materials and research instruments as possible, while the second aimed to gain deep description about effectiveness of the authentic task.

For this current study, the authentic task consisted of five activities, that is, investigating morphological structure of a certain plant that theoretically has anomalous structure in stem, identifying anatomical structure of the plant, writing a scientific journal about the plant, presenting orally the important aspects of the plant, and presenting a poster about the plant. In this case, the students' performance included scientific journal writing, oral presentation, and poster presentation were assessed by authentic assessment.

\section{Data collection}

For collecting data, this current study relies on three techniques. The first was observation which aimed to collect information about obstacles that occurred during implementation of the authentic task. The observation result was recorded by observation sheet and field notes. The second was semi-structured interview which was conducted for collecting data included students' feeling, opinion, and experience during implementation of the authentic task. During the activity, four respondents were involved. They were the highest and the lowest achiever group members, and the highest and lowest achiever students. The last was test of students' learning achievement included performances on the authentic task consisting of scientific journal writing, oral presentation, and poster presentation which were assessed by authentic assessment and knowledge mastery of topic under study that was assessed by paper-and-pencil test. In this case, the authentic assessment was designed in form of numerical rating scale with four levels of achievement 
and was completed by the lecturer. Differently, the paperand-pencil test consisted of multiple choice, short answer, fill-in-the blank, and essay questions and was completed by students.

\section{Data analysis}

This study collected both qualitative and quantitative data. The former was collected from observation sheet, field note, and interview. Those original data, then, were analyzed descriptively. The second data were collected from authentic assessment and paper-and-pencil test. The raw data of students' performance were counted firstly using formula as follows:

$$
\text { Students'score }=\frac{\text { score }}{\text { maximum score }} \times 100 \%
$$

The students' performance was good if the score met the minimum mastery criteria which were determined by the experienced lecturer, that is, $75 \%$. Furthermore, the raw data of paper-and-pencil test were counted using the following formulas.

$$
\begin{aligned}
& \% \text { Individual Mastery }=\frac{\sum \text { indicators mastered by each student }}{\text { total number ofindicators }} \times 100 \% \\
& \% \text { Classical Mastery }=\frac{\sum \text { mastered students for each indicator }}{\text { total number of students }} \times 100 \% \\
& \% \text { Mastered Indicator }=\frac{\sum \text { indicator mastered by the class }}{\text { total number of indicators }} \times 100 \%
\end{aligned}
$$

If the values met the minimum mastery criteria which were determined by the experienced lecturer, that is, $75 \%$, it can be said that the students had mastered the topic of study.

\section{RESEARCH FINDINGS AND DISCUSSION}

\section{Students' Performance Result}

For this study, the assessed students' performance included scientific journal writing, oral presentation, and poster presentation skills. The result of the students' performance is shown briefly in the following chart.

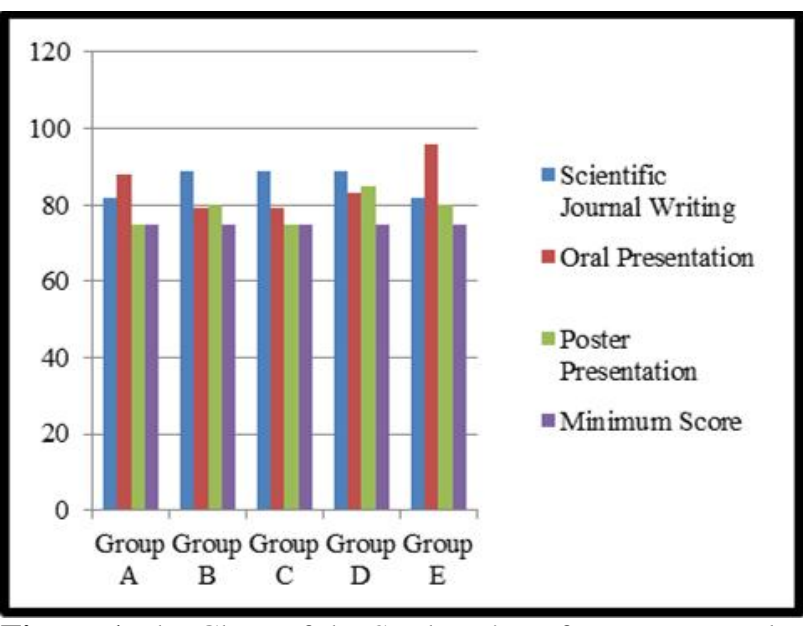

Figure 1 The Chart of the Students' Performance Result

Based on the students' performance result as shown in Figure 1, the performance scores included journal writing, oral presentation, and poster presentation of the five involved groups in this study were in the upper level of the minimum score, except to group C's and group D's poster presentation scores which were in the same level of it. Thus, based on the performance scores, overall, the students had good performance on the authentic task. It means that the implemented authentic task had good impact on students' performance. The similar findings were also reported by Gulikers et al. ${ }^{[14]}$; by Koenders ${ }^{[20]}$; by Woo et al. ${ }^{[27]}$; and by $\mathrm{Neo}$ and $\mathrm{Neo}{ }^{[23]}$ in their study using an authentic task.

The good performances of the students in this study can be explained for two reasons. Firstly, the authentic task increases students' motivation toward learning. As students commented in the interview section "I thought that the task was interesting because it was a new thing...". The statement describes students' intrinsic motivation, that is, a motivation to take action due to personal interest, curiosity, enjoyment, or satisfaction ${ }^{[2]}$ [25] [28]. The explanation is also supported by studies conducted by Koenders ${ }^{[20]}$ and $\mathrm{Neo}$ and Neo ${ }^{[23]}$. According to them, the authentic task encouraged students to become active and highly motivated learners. Furthermore, Cumming and Maxwell ${ }^{[8]}$ argued that motivation enables to enhance learners' cognitive engagement and thereby increase learning achievement. Similarly, Woolfolk et al. [28] asserted that students' interest toward learning has positive effect on the higher learning achievement. Secondly, the authentic task provides an authentic context ${ }^{[18]}$ in which students' learning process and performance occur best ${ }^{[6]}$. Similarly, Honebein et al. ${ }^{[19]}$ in their study observed that learning will be easier when students are engaged in authentic context since the context helps them to construct their own understanding.

\section{Students' Knowledge Mastery Result}

In this study, the students' knowledge mastery of stem anatomy topic was assessed by paper-and-pencil test. The students' mastery level of the topic was

\begin{tabular}{|c|c|c|c|c|c|c|c|c|c|c|c|c|c|}
\hline \multirow{2}{*}{$\begin{array}{l}\text { Stu- } \\
\text { dent }\end{array}$} & \multicolumn{12}{|c|}{ Indicators } & \multirow{2}{*}{ Exp. } \\
\hline & 1 & \begin{tabular}{l|l}
2 & \\
\end{tabular} & 3 & 4 & 5 & 6 & 7 & 8 & 9 & 10 & 11 & 12 & \\
\hline 1 & 1 & 1 & 1 & 1 & 0 & 0 & 1 & 0 & \begin{tabular}{l|l}
1 \\
\end{tabular} & 1 & 1 & 0 & $\mathrm{~nm}$ \\
\hline 2 & 0 & 1 & \begin{tabular}{l|l}
1 & \\
\end{tabular} & 1 & 0 & 0 & 1 & 1 & 1 & 1 & 1 & 0 & $\mathrm{~nm}$ \\
\hline 3 & 1 & 1 & 1 & 1 & 1 & 1 & 1 & 0 & 1 & 1 & 1 & 0 & $m$ \\
\hline 4 & 0 & 1 & 1 & 1 & 0 & 0 & 1 & 0 & 1 & 0 & 1 & 0 & $\mathrm{~nm}$ \\
\hline 5 & 1 & 1 & 1 & 1 & 1 & 1 & 1 & 1 & 1 & 1 & 1 & 1 & $\mathrm{~m}$ \\
\hline 6 & 1 & 1 & 1 & $\begin{array}{ll}1 \\
\end{array}$ & 1 & 0 & \begin{tabular}{l|l}
1 \\
\end{tabular} & 0 & I & 1 & 1 & 0 & $\mathrm{~m}$ \\
\hline 7 & 1 & 1 & 1 & 1 & 1 & 0 & 1 & 0 & 1 & 1 & 1 & 1 & $\mathrm{~m}$ \\
\hline 8 & 1 & 1 & 1 & 1 & 1 & 1 & 0 & 1 & 1 & 1 & 1 & 1 & $\mathrm{~m}$ \\
\hline 9 & 0 & \begin{tabular}{l|l}
1 & \\
\end{tabular} & 1 & 1 & 1 & 1 & 0 & 0 & 1 & 1 & 1 & 0 & $\mathrm{~nm}$ \\
\hline 10 & 1 & 1 & 1 & 1 & 1 & 1 & 1 & 1 & 1 & 1 & 1 & 1 & $\mathrm{~m}$ \\
\hline 11 & 1 & \begin{tabular}{l|l}
1 \\
\end{tabular} & 1 & 1 & 1 & 0 & 1 & 0 & 1 & 1 & 1 & 1 & $\mathrm{~m}$ \\
\hline 12 & 1 & 1 & 1 & 1 & 1 & 1 & 1 & 1 & 1 & 1 & 1 & 1 & $\mathrm{~m}$ \\
\hline 13 & 1 & 1 & 1 & 1 & 1 & 0 & 1 & 0 & 1 & 0 & 1 & 0 & $\mathrm{~nm}$ \\
\hline 14 & 1 & 1 & 1 & 1 & 1 & 1 & 1 & 1 & 1 & 1 & 1 & 0 & $\mathrm{~m}$ \\
\hline 15 & 1 & 1 & 1 & 1 & 1 & 1 & 1 & 1 & 1 & 1 & 1 & 1 & $\mathrm{~m}$ \\
\hline 16 & 1 & 1 & 1 & $\begin{array}{ll}1 \\
\end{array}$ & 1 & 1 & $\begin{array}{ll}1 \\
\end{array}$ & 1 & 1 & 1 & 1 & 0 & $m$ \\
\hline 17 & 0 & 1 & 1 & 1 & 0 & 0 & 1 & 0 & 1 & 1 & 1 & 1 & $\mathrm{~nm}$ \\
\hline 18 & 0 & 1 & 1 & 1 & 1 & 0 & 1 & 0 & 1 & 1 & 1 & 0 & $\mathrm{~nm}$ \\
\hline 19 & 1 & 1 & $\mathrm{I}$ & 1 & 1 & 1 & 1 & 0 & 1 & 1 & 1 & 0 & $\mathrm{~m}$ \\
\hline 20 & 0 & 1 & 1 & 1 & 0 & 0 & 1 & 1 & 1 & 1 & 1 & 0 & $\mathrm{~nm}$ \\
\hline 21 & 1 & 1 & 1 & 1 & 0 & 0 & 1 & 0 & 1 & 1 & 1 & 0 & $\mathrm{~nm}$ \\
\hline 22 & 1 & 1 & 1 & 1 & 1 & 0 & \begin{tabular}{l|l}
1 \\
\end{tabular} & 1 & \begin{tabular}{l|l}
1 \\
\end{tabular} & 1 & 1 & 0 & $\mathrm{~m}$ \\
\hline 23 & 0 & 1 & 1 & $\mathrm{I}$ & 0 & 0 & 1 & 0 & 1 & 1 & 1 & 0 & $\mathrm{~nm}$ \\
\hline 24 & 1 & 1 & 1 & 1 & 1 & 1 & 1 & 1 & 1 & 1 & 1 & 0 & $m$ \\
\hline 25 & 1 & 1 & 1 & 1 & 1 & 1 & 1 & 1 & I & 1 & 1 & 1 & $\mathrm{~m}$ \\
\hline Exp. & $\mathrm{m}$ & $\mathrm{m}$ & $\mathrm{m}$ & $\mathrm{m}$ & $\mathrm{m}$ & $\mathrm{nm}$ & $\mathrm{m}$ & $\mathrm{nm}$ & $\mathrm{m}$ & $\mathrm{m}$ & $\mathrm{m}$ & $\mathrm{nm}$ & $96 \mathrm{CM}$ \\
\hline $0 \% \mathrm{MII}$ & & & & & & & 75 & & & & & & $=60$ \\
\hline
\end{tabular}
determined by percentage of classical and indicators mastery as shown in the following table.

Table 1 Percentage of Classical and Indicators Mastery 


\section{Notes:}

Indicators:

1. To determine the meaning of primary stem.

2. To determine three kinds of primary meristem which develop to three kinds of tissues in primary stem.

3. To identify tissues which build a general structure of primary stem.

4. To analyze difference between primary stem structure of dicotyledon and monocotyledon.

5. To determine the meaning of secondary stem.

6. To determine secondary growth process that occurs in dicotyledon's stem.

7. To explain secondary growth process that occurs in monocotyledon's stem.

8. To identify tissues which arrange a general structure of dicotyledon's secondary stem.

9. To explain the meaning of anomalous structure in stem.

10. To analyze characteristic of anomalous structure in primary stem of various plants.

11. To analyze characteristic of anomalous structure in secondary stem of various plants.

12. To analyze the cause of anomalous structure in secondary stem of various plants.

$1=\mathrm{m}$ (mastered)

$0=\mathrm{nm}$ (not mastered)

$\% \mathrm{CM}$ (percentage of classical mastery)

$\% \mathrm{MI}$ (percentage of mastered indicators)

Table 1 shows that the percentage of classical mastery of the topic, that is $60 \%$, was less than the minimum mastery criteria which was determined by the experienced lecturer. It means that the class as a whole had not mastered yet this topic. Nevertheless, based on the percentage of mastered indicators, that is, $75 \%$ which met the minimum mastery criteria, it can be said that the topic of study had been mastered by students. Since it was criterion referenced test which was indicated by individual and classical mastery ${ }^{[25]}$, therefore, overall the involved students had not mastered yet this topic.

It means that, contrary to the previous research finding that students who learned through authentic learning experiences got better scores on traditional paper-and-pencil test than the students who were taught using traditional transmission method ${ }^{[5]}$, the implemented authentic task of this study could not help students to master the topic. However, the similar finding was also reported by Albanese and Mitchell ${ }^{[1]}$ in their study about problem-based learning. They found that students were better in problem solving skills, but they were worse in basic knowledge acquisition.

The fact can be explained for four reasons. Firstly, in this case, the students were required to construct their own knowledge by themselves based on the observation and related concepts. However, because most students' skill in making microscope slides could not develop well and the secondary stem was hard enough, their cross section picture of secondary stem was unclear and could not be identified. As a result, students cannot learn the secondary stem structure well. It was proved by three secondary stem anatomy indicators (No. 6, 8, and 12) that had not mastered yet by the students (see Table 1). Besides, the students did not learn the subtopic from the available textbooks since usually they learn topics from the lecturer's explanation at the beginning of the lesson. It was supported by research which was conducted by Good and Brophy ${ }^{[12]}$. In their study, they reported that students got more knowledge from teachers' explanation. Furthermore, Albanese and Mitchell ${ }^{[1]}$ in their study concluded that students who got less "cognitive scaffoldings" tend to got low scores in basic content examination (p. 57).

Secondly, since the task was conducted in groups and each group should identify different specimen so that students were difficult to understand the anomaly structure occur in the other groups' specimens. It was proved by indicator number 12 that had not mastered yet (see Table 1). In accordance with this view, Engelkamp and Dehn ${ }^{[11]}$ in their study concluded that learning was easier when students do the task physically rather than only read the task instructions or observe the task demonstration.

Thirdly, the students were anxious during implementation of the authentic task, as a student's comment "I am afraid I will get bad score in this subject...". The similar finding was also reported by Cassady and Johnson ${ }^{[7]}$ in a study about the effect of anxiety on academic performance. They found that there was a significant association between higher levels of test anxiety and lower test scores. Related to it, Bandalos et al. ${ }^{[3]}$ proposed three reasons. First of all, anxiety makes students difficult to receive new information in the first place. Besides, anxious students tend to have difficulty to transfer their learning. Consequently, anxiety makes students difficult to demonstrate their knowledge during test.

Finally, due to limited time, the students had not enough time to construct well their own understanding. As an experienced lecturer explained in the field notes that students need enough time to build understanding. Similarly, Woolfolk et al. ${ }^{[28]}$ asserted that for successful learning, students need more time for active constructing knowledge activities and social interaction for knowledge construction. Besides, Claxton (as cited in ${ }^{[5]}$ ) suggested "an authentic task needs ample time for reflection and maturation" (p. 319).

Interview Result 
Based on the interview result, at the beginning of the authentic task implementation, three respondents felt afraid. However, when conducting the task, they could complete it enjoyably due to the collaboration among the group members and lecturer's assistance. It means that this task could provide successfully the opportunity for students to collaborate. The similar findings were also observed by Arends ${ }^{[2]}$ and Woolfolk et al. ${ }^{[28]}$. According to them, collaboration during authentic task encouraged students to be motivated learners, and thereby increasing their involvement toward the complex task. Moreover, according the respondents except the 4th respondent, the task was interesting. It means that the task could motivate intrinsically the students to learn.

Regarding to the task authenticity, the interview result shows that the four respondents thought the task was authentic and useful for their future life. Thus, the developed task was authentic not only in researcher' view as developer, but also in students' perceptions. Those facts might be one of the reasons why the students in this study had good performance on the authentic task. As Herrington and Herrington ${ }^{[16]}$ revealed that a task will affect positively on students' learning when they think that the task are relevant to their real-life. Equally, Huang (as cited in ${ }^{[13]}$ ) thought that tasks which relevant to the reality can encourage students to intensively include in the learning process, so that it will increase their learning outcome. In a similar fashion, Gulikers et al. ${ }^{[14]}$ proved that as students think the task is relevant to their real future life, they will be motivated to deeply learn the material which would give the best performance.

Furthermore, related to the students' comprehension toward the concepts, two respondents showed different perceptions. The 3rd respondent who got the highest score stated that the task could improve her understanding toward the concepts because it enabled students to connect their prior knowledge to the new information. Conversely, the 4 th respondent who got the lowest score thought that the concepts could not be understood well since there was no explanation about them at the beginning. Based on the fact, the higher achiever student tends to perceive the task positively, whereas the lower one perceives the task negatively. Thus, students' perception of the learning can affect their learning achievement. This finding is also supported by studies which were conducted by Lizzio et al. [21], Gulikers et al. ${ }^{[14]}$, and Gulikers et al. ${ }^{[15]}$. Furthermore, Biggs (as cited in ${ }^{[14]}$ ) clarified that students' perception can affect learning in two ways. Firstly, it affects directly on students' outcome. Secondly, it influences on learning outcomes indirectly by affecting students' study approach, that is, deep or surface learning.

Observation Result
The observation result proposed four main obstacles during implementation of the authentic task. Firstly, some students still confused with the task. Arguably, it was resulted from ill-define characteristic of the authentic task. As Doyle (as cited in ${ }^{[22]}$ ) argued that ill-structured task can cause students' ambiguity about the appropriate action and the task goal. Besides, the learners' confusing occurs because they were usually provided with structured-learning tasks. It was in accordance with Herrington et al. [18] statement that students are commonly provided with well-designed leaning tasks which have straightforward steps, procedures and hints to get one correct answer. As a result, students confuse when they are required to identify the tasks, related subtasks, and related appropriate performance by themselves, as the characteristics of the ill-structured task. Secondly, students' difficulty to make microscope slides may be caused by it is new activity for the students. As Billett [4] argued that in order to be professionals, students need to be involved in "an extensive period of practice" (p. 1).

Thirdly, the students were difficult identifying anatomical structure of plants. It could be explained for three reasons. The hardness of the stem caused cross section made by students was bad, so that, they got unclear and unidentified slides. Consequently, they could not learn the stem's anatomical structure well. Besides, the students have not learned the concepts from the available textbooks yet since usually they learn them from the lecturers' explanation. Furthermore, there was only limited time to construct knowledge from the observation results during the task.

Lastly, the available time was not enough for implementing the authentic task optimally. According to Herrington et al. ${ }^{[17]}$, an authentic task is suitable to be implemented for one semester or for entire course. Similarly, Neo and Neo ${ }^{[23]}$ and Woo et al. ${ }^{[27]}$ conducted their studies about authentic task for 13-14 weeks. Furthermore, Claxton (as cited in ${ }^{[5]}$ ) suggested "an authentic task needs ample time for reflection and maturation" (p. 319).

\section{CONCLUSION}

In conclusion, the implemented authentic task in this study had positive impact on students' performance, but it could not help the whole students to master the topic of study. Nevertheless, the task was perceived as authentic one by both the developer and the students. However, there were four difficulties which occurred during implementation of the authentic task included students' confusion of the task, students' difficulty to make microscope slides, students' difficulty to identify plants anatomical structure, and the limited time. Overall, based 
on the results, the implemented authentic task was not effective for the learners in order to get good learning achievement due to the difficulties. Therefore, in designing a well authentic task, the educators or developer need to think not only the task, but also students' skills and time allocation.

\section{REFERENCES}

Albanese, M., \& Mitchell, S. (1993). Problem-based learning: A review of literature on its outcomes and implementation issues. Academic Medicine, 68, 5261.

Arends, R. I. (2004). Learning to teach (6th ed.). New York: McGraw-Hill.

Bandalos, D. L., Yates, K., \& Thorndike-Christ, T. (1995). Effects of math self-concept, perceived selfefficacy, and attributions for failure and success on test anxiety. Journal of Educational Psychology, 87(4), 611-623.

Billett, S. (2010). Learning through practice. In S. Billett (Ed.), Learning through practice: Models, traditions, orientations, and approaches (pp. 1-20). New York: Springer.

Blum, K. (2003). Enhancing understanding and attitude by authentic learning experiences. In D. Fisher \& T. Marsh (Eds.), Proceedings of the Third Conference on Science, Mathematics and Technology Education 2007 (pp. 317-328). Perth: Curtin University of Technology.

Brown, J. S., Collins, A., \& Duguid, P. (1989). Situated cognition of and the culture of learning. Educational Researcher, 18(1), 32-42.

Cassady, J. C., \& Johnson, R. E. (2002). Cognitive anxiety and academic performance. Contemporary Educational Psychology, 27, 270-295.

Cumming, J. J., \& Maxwell, G. S. (1999). Contextualizing authentic assessment. Assessment in Education: Principles, Policy \& Practice, 6(2), $177-$ 194.

Cutler, D. F., Botha, T., \& Stevenson, D. W. (2007). Plant anatomy: An applied approach. Malden, USA: Balckwell Publishing.

Darling-Hammond, L., Ancess, T., \& Falk, A. (1995). Authentic assessment in action: Studies of schools and students at work. New York: Teacher College Press.

Engelkamp, J., \& Dehn, D. M. (2000). Item and order information in subject-performed tasks and experimenter-performed tasks. Journal of Experimental Psychology: Learning, Memory, \& Cognition, 26, 671-682.

Good, T., \& Brophy, J. (2008). Looking in classrooms (10th ed.). Boston: Allyn \& Bacon.

Gulikers, J. T. M., Bastiaens, T. J., \& Martens, R. L. (2005). The surplus value of an authentic learning environment. Computer in Human Behavior, 21, 509-521.
Gulikers, J. T. M., Bastiaens, T. J., Kirschner, P. A., \& Kester, L. (2006). Relations between student perceptions of assessment authenticity, study approaches and learning outcome. Studies in Educational Evaluation, 32, 381-400.

Gulikers, J. T. M., Kester, L., Kirschner, P. A., \& Bastiaens, T. J. (2008). The effect of practical experience on perceptions of assessment authenticity, study approach, and learning outcomes. Learning and Instruction, 18, 172-186.

Herrington, J., \& Herrington, A. (1998). Authentic assessment and multimedia: How university students respond to a model of authentic assessment. Higher Educational Research \& Development, 17, 305-322.

Herrington, J., Reeves, T. C., \& Oliver, R. (2006). Authentic tasks online: A synergy among leaner, task, and technology. Distance Education 27(2), 233-247.

Herrington, J., Reeves, T. C., \& Oliver, R. (2010). A guide to authentic e-learning. New York: Routledge.

Honebein, P. C., Duffy, T. M., \& Fishman, B. J. (1993). Constructivism and the design of learning environments: Context and authentic activities for learning. In T. M. Duffy, J. Lowyck, \& D. H. Jonassen (Eds.), Designing environments for constructive learning (NATO ASI Series F: Computer and systems sciences, Vol. 105, pp. 87108). Berlin: Springer-Verlag.

Koenders, A. (2006). An authentic online learning environment in university introductory biology. In T. Herrington \& J. Herrington (Eds.), Authentic learning environment in higher education (pp. 4860). Hershey, USA: Information Science Publishing.

Lizzio, A., Wilson, K., \& Simons, R. (2002). University students' perceptions of the learning environment and academic outcomes: Implications for theory and practice. Studies in Higher Education, 27, 27-51.

Lodewyk, K. R., \& Winne, P. H. (2005). Relations among the structure of learning tasks, achievement, and changes in self-efficacy in secondary students. Journal of Educational Psychology, 97(1), 3-12.

Neo, M., \& Neo, T-K. (2010). Students' perceptions in developing a multimedia project within a constructivist learning environment: A Malaysian experience. The Turkish Online Journal of Educational Technology, 9(1).

Parker, L., \& Rennie, L. (1998). Equitable assessment strategies. In B. J. Fraser \& K. Tobin (Eds.), International Handbook of Science Education (pp. 897-939). Dordrecht: Netherlands: Kluwer Academic Publishers.

Slavin, R. E. (2012). Educational psychology: Theory and practice (10th ed.). New Jersey: Pearson Education.

Timmerman, B. E., Strickland, D. C., \& Carstensen, S. M. (2008). Curricular reform and inquiry teaching in biology: where are our efforts most fruitfully 
invested?. Integrative and Comparative Biology, 48(2), 226-240.

Woo, Y., Herrington, J., Agostinho, S., \& Reeves, T. C. (2007). Implementing authentic tasks in web-based learning environments. Educause Quarterly, 30(3), 36-43.

Woolfolk, A., Hughes, M., \& Walkup, V. (2008). Psychology in education. London: Pearson Education. 